\title{
Irrigation patterns and scheduling of a telecontrolled irrigation district in north-eastern Spain
}

\author{
by \\ Stambouli T. ${ }^{*}$, Zapata N. ${ }^{2}$ and Faci J.M. ${ }^{1}$ \\ 1 Soil and Irrigation Unit (EEAD-CSIC Associated Unit), Agrifood Research and Technology Center \\ of Aragón (CITA-DGA), Gobierno de Aragón. Avda. Montañana 930, 50059, Zaragoza (Spain). \\ 2 Dept. Soil and Water, Experimental Station of Aula Dei (EEAD-CSIC), Apdo. 202, 50080 Zaragoza \\ (Spain). \\ * Corresponding Author: \\ Stambouli Talel \\ Soil and Irrigation Unit (EEAD-CSIC Associeted Unit), Agrifood Research and Technology Center of \\ Aragón (CITA-DGA), Gobierno de Aragón. Avda. Montañana 930, 50059, Zaragoza (Spain). \\ Phone: +34976713875 . \\ Fax: + 34976716335 . \\ Email: tstambouli@aragon.es \\ Website: http://wwww.cita-aragon.es/
}

\section{Abstract}

Over the last ten years, telecontrol systems have been incorporated into the majority of modern collective pressurized irrigation networks in Spain. This type of infrastructure provides many opportunities for irrigation management but actually, in Spain, is only used for standardized network operations. The Candasnos irrigation district (CID), located in northeastern Spain, is equipped with this system, and contains a variety of different pressurized systems. Telecontrol data and crop water requirements were used to analyze the evolution of irrigation performance (SIPI) of maize, alfalfa and stone fruits. Irrigation guidelines for stone fruit were analyzed and compared to those of standard and regulated deficit irrigation (RDI) irrigation strategies. Ten solid set irrigation systems were monitored to determine on-farm irrigation patterns. The average SIPI of maize, alfalfa and peach was $83 \%, 107 \%$ and $123 \%$, respectively. The average SIPI showed a high irrigation performance, but the spatial and temporal variability of SIPI showed possibilities for improvement. Deficit irrigation practices were conducted on peach trees, but not adjusted to the recommended RDI strategy. The results of plot monitoring showed crop differences on irrigation time per event (1-1.5 $\mathrm{h}$ in maize and 2-3 $\mathrm{h}$ in alfalfa) and on time interval between irrigation (larger in alfalfa than in maize). The short and frequent irrigation timing for corn crop could be a disadvantageous practice since it yielded high evaporation losses from crop intercepted water. Two irrigation patterns were established at the CID: the first was characterized by structured irrigation schedules and the second was characterized by weekly changes in the irrigation schedule. The second pattern was more commonly employed in solid set systems than in those with pivots. The analysis of telecontrol data following this methodology could be easily implemented in the daily routines of the district office to improve irrigation management at the plot level. Further, telecontrol data can be an important tool for promoting and facilitating controlled deficit irrigation strategies in stone fruits. 


\section{Key words}

Irrigation district; Irrigation scheduling; Telecontrol Irrigation System; Centre pivot; Solid set; Drip irrigation, Regulated deficit irrigation, irrigation performance indices. 


\section{Abbreviation}

ADOR

ARIS

CDI

CID

$\mathrm{CU}$

EP

$E T_{0}$

ID

Kc

$K_{r d}$

NCDIR

NIR

SIPI

VC

WDEL
=Irrigation district management software; Ador is a Spanish word derived from Arabic and means to turn (Pláyan et al. 2007)

=Annual relative irrigation supply

$=$ Controlled deficit irrigation

$=$ Candasnos irrigation district

=Christiansen coefficient of uniformity

=Effective precipitation

$=$ Reference evapotranspiration

=Irrigation depth

$=$ Crop coefficients

$=$ Reduction coefficient for controlled deficit irrigation

$=$ Net controlled deficit irrigation requirements

$=$ Net irrigation requirements

=Seasonal irrigation performance index

=Variation coefficient

$=$ Wind drift and evaporation losses 


\section{Introduction}

In the last decade, national and regional policies have encouraged the modernization of traditional irrigated land in Spain. The National Irrigation Plan was approved by the Spanish Government in 2002. This National Irrigation Plan allocated $61 \%$ of its total funds to the modernization of irrigation systems and infrastructures until 2008 (Forteza Del Rey, 2002). Current irrigation projects in Spain include the modernization of traditional irrigation systems and conversion to pressurized irrigation systems.

In Spain, the modernization of irrigation networks has been accompanied by the installation of modern telecontrol irrigation systems and has offered new methods for the control and management of irrigation systems. Telecontrol irrigation systems have become increasingly popular in Spanish irrigation districts and have provided water savings of $30 \%$ to $60 \%$, improved crop productivity, optimized the use and timing of fertilizer applications and improved control of large irrigated land extensions (Damas et al. 2001). Control utilities have been rapidly incorporated in daily irrigation district management; however, real time irrigation management utilities have not been widely employed. Most irrigated land in Spain is supervised by user associations, which include thousands of individual plots with an average surface area of 1 ha (Damas et al. 2001). Telecontrol irrigation systems allow the centralized control of large regions of irrigated land (hundreds of control points and hydrants, thousands of hectares and inter-node distances of several kilometres) without the need to extend electricity to each hydrant. Moreover, installation and maintenance costs are minimized in centralized telecontrol irrigation systems (Damas et al. 2001). Moreover, telecontrol systems provide real-time water-use information on individual plots, allowing the analysis of irrigation performance and enabling personalized advising, which can improve water use at the plot level. However, the centralized control of different plots by user association agencies is rarely conducted in irrigation districts in Spain. Moreover, 
studies on the use of remote control and the supervision of on-farm irrigation management practices at the district level have not yet been conducted.

Irrigation performance is usually analyzed by determining a specific set of indicators (Molden and Gates 1990; Malano and Burton 2000; Playán and Mateos 2006). To conduct important assessments, the indicators should be locally adapted to describe the idiosyncrasies of the irrigated area (Lorite et al. 2004a). Due to the availability of water-use information at the individual plot, farmer or hydrant level, a meaningful assessment of irrigation performance can be conducted by determining the average performance indicators of the main crops in the area and assessing the variability among irrigation systems and farmers. If the average performance values are reasonable, then high variability among farmers indicates that irrigation management strategies can be improved (Fernandez et al. 2007). Telecontrol utilities offer continuous water use data at the hydrant level that can be used for this purpose.

Irrigation performance studies on seasonal on-farm water meter readings within irrigation districts have been performed for different irrigation schemes. For instance, Faci et al. (2000), Dechmi et al. (2003 a,b) and Lecina et al. (2005) analyzed the irrigation performance of sprinkler (the first two papers) and (the last paper) surface-irrigated districts in the Ebro Valley. Lorite et al. (2004a, b) determined the variability among farmers and seasons in a sprinkler and drip-irrigated scheme in the Guadalquivir Valley. Fernandez et al. (2007) presented an on-farm irrigation performance analysis of three greenhouse irrigation schemes in southern Spain.

In the present study, irrigation patterns were evaluated using continuous water use data from the telecontrol irrigation system of the Candasnos irrigation district (CID) during 2009. Irrigation water use at the individual plot level was also evaluated and was compared to the crop irrigation requirements. Moreover, the potential uses of telecontrol data for the management of irrigation systems were explored. In addition, the current irrigation schedule 
at the CID and the variability among crops, irrigation systems and farmers were analyzed. Irrigation performance indices throughout the crop cycle of the main crops, an aspect that has not been sufficiently studied in the literature, were also evaluated in the present study. The CID was selected due to its diverse irrigation systems (solid set sprinkler irrigation, pivots and drip irrigation), the availability of telecontrol data and the variety of crops. The objectives of the present study were as follows:

1. Characterize the adequacy of irrigation application to crop irrigation requirements by analyzing the temporal variability of the SIPI.

2. Characterize the irrigation patterns of different crops and irrigation systems (solid set, center pivot and drip irrigation) using telecontrol data.

3. Characterize on-farm block irrigation sequences of solid set sprinkler-irrigated plots by monitoring the hydraulic blocks.

4. Identify ways to improve water use in the district. 


\section{Material and Methods}

\section{The Candasnos Irrigation District}

The Candasnos irrigation district (CID) belongs to the Riegos Del Alto Aragón irrigation scheme (Figure 1). The CID is located in the municipality of Candasnos (Huesca Province in the region of Aragón), and Aragón is located in the Ebro River Valley of north-eastern Spain. Aragón is an important agricultural production region and is equipped with modern irrigation systems. The main crops in Aragón are cereals, alfalfa and fruit trees. The CID covers a total area of 6,400 ha, of which 5,745 ha are irrigated lands. Irrigation water comes from the Canal de Sastago, which diverts water to a reservoir with a storage capacity of $210,000 \mathrm{~m}^{3}$. The canal and reservoir are located $70 \mathrm{~m}$ above the highest topographical point of the irrigated land of the district. As a result, energy is not required to irrigate plots in the CID (the CID does not possess a pumping station). Sprinklers are the main irrigation system in the study region, and $73 \%$ of the irrigated area is sprinkler irrigated. $7 \%$ of the area is irrigated by drip irrigation and the remainder 20\% was not equipped. Sprinkler irrigation systems in the study region are diverse, and a significant number of pivots (1,838 ha) and solid sets (2,344 ha) are employed. The quality of the irrigation water is high because it comes from melting ice in the Pyrenees' mountains of northern Spain.

Information about crop production for alfalfa and maize were provided by a local study based on farmer's interviews (CITA-CHE Unpublished data).

A soil sampling campaign was performed during the winter of 2009 to characterize the soil physical properties related to irrigation (soil holding capacity and texture). A total of 80 sampling points were selected covering the whole CID, and the soil was collected to a depth of $1.2 \mathrm{~m}$ or to the limiting depth. Samples were collected every $0.3 \mathrm{~m}$, and the stoniness (percentage of coarse fragments $>2 \mathrm{~mm}$ ), texture, field capacity and wilting point of the soil were determined according to the methods of the Soil Survey Laboratory (2004). Volumetric 
stoniness (S, \%) was determined for each soil sample from the weigh of fractions above and below $2 \mathrm{~mm}$, soil bulk density $\left(\rho_{b}, \mathrm{Mg} \mathrm{m}-3\right)$ and the stone density. Soil bulk density and stone density were estimated as 1.40 and $2.65 \mathrm{Mg} \mathrm{m}^{-3}$, respectively, in agreement with previous works in the area (Playán et al. 2000).

\section{The Seasonal Irrigation Performance Index of Corn, Alfalfa and Stone Fruits.}

ADOR software (Playán et al. 2007) is currently used to manage the irrigation district in CID, and water delivery to farmers is conducted according to a previous water order scheme. This type of scheme is commonly used in surface irrigation systems and pressurized irrigation systems to control energy costs. Fortunately, energy costs are not a problem in the CID because irrigation water does not have to be pumped. Nevertheless, an advanced water orders scheme is used in the study region due to the low reservoir capacity. Moreover, the water must be ordered to the Ebro River Basin Agency two days before the water is released into the district. To apply irrigation, farmers must fill out a water order form by phone or directly in the district office, which includes the requested delivery date (a minimum of two days in advance), start time and total irrigation time.

The district files the water order and fits the order into the water delivery schedule. The ADOR network analysis module is used to determine if a water order can be physically delivered. Namely, the total water flow demand of the network in the CID is evaluated and it is verified that no over-exploitation of the irrigation network occurs. During the order confirmation process, the parameters of a water order can be altered by the district managers. Finally, the district verifies the water order and records the actual date, start time and volume of water applied to the field.

The irrigation network was provided with a telecontrol system (communicated by cable). The telecontrol system has been used by the district managers to perform the remote readings of the hydrant flow meters, to control incidences in the hydraulic 
network (breakdowns, opening and closing of the hydraulic valves), however, the system has not been used to analyse the water management standards. In 2009, the CID telecontrol system was modernized, and the communication software was upgraded to a more user friendly version. Since then, the telecontrol system remains underutilized by the district. The telecontrol system allows the water volume consumed by individual hydrants to be measured remotely; however, the district manager performs manual field readings of the water meters in the hydrants. Even if the hydrant is shared by several plots, the water consumed by each farmer can be adequately divided by the telecontrol data and the demand of the farmers. Currently, the telecontrol system is programmed to collect water volume data at each hydrant every six hours.

The irrigation network of the CID is composed of three manifolds (TPN1, TPN2 and TPNV) that act as independent networks. Each manifold has 3 or 4 irrigation control units that receive data from 18 to 72 hydrants (field units or remote units). During the present study, a communication error was detected in an irrigation unit in TPN1 (corresponding to 31 hydrants and 802 ha). The problem was not detected by the district manager, indicating that the telecontrol data were underutilized by the district. The area without data was excluded from the monthly analysis; however, this area was included in the seasonal analysis because the final volume of water was obtained from the hydrant water meters by the manager (manually read).

The telecontrol data were used to calculate the volume of water applied to each plot throughout the crop cycle, and the results were compared to the net irrigation requirements (NIR). The NIR for each crop were considered equal for the entire irrigation district. The seasonal irrigation performance index (SIPI, Equation 1) was used to analyze irrigation performance in the CID. The SIPI (Faci et al. 2000) was defined as the ratio of the net 
irrigation requirement (NIR, Equation 2) to the volume of irrigation water supplied to the crops. The seasonal irrigation performance index is a simplification of the irrigation efficiency standard defined by Burt et al. (1997) and Clemmens and Burt (1997). Specifically, if a crop is water stressed, then the SIPI will be greater than $100 \%$. Moreover, if the SIPI is greater than the application efficiency of the irrigation system, then the crop will be water stressed (Faci et al. 2000). The SIPI is commonly used as a seasonal parameter; however, in the present study, SIPI values were computed for short to seasonal crop periods to study the temporal variability of crop irrigation performance.

In 2009, monthly SIPI values for corn were calculated throughout the irrigation season to study water use in different phases of the crop cycle. For each plot of corn, the monthly cumulative SIPI was computed, and the results were spatially and temporally analyzed by GIS. To analyze the water use patterns of alfalfa, the SIPI of each cut was independently computed. Because the irrigation interval after a cut is usually longer than the regular irrigation interval, telecontrol data were used to determine the date of alfalfa cuts.

$$
\text { SIPI }=\frac{\text { Net Irrigation Requirements (NIR) }}{\text { Irrigation Depth (ID) }}
$$

Crop distribution in the CID varied from year to year, depending on the market demands. The crop cultivated in each plot of the CID during 2009 was obtained from the ADOR database. The crop distribution was spatially and numerically analyzed, and the reference evapotranspiration $\left(\mathrm{ET}_{0}\right)$ was calculated on a daily basis by applying the Penman-Monteith (Smith 1993) method to the 2009 meteorological data. The SIAR agro-meteorological station located in the Candasnos municipality (SIAR Candasnos) was used for meteorological data. The SIAR network of agrometeorological stations was created in 1998 by the Spanish Ministry of Agriculture (MARM) (http://www.mapa.es/siar/Informacion.asp). This network covers most irrigated areas in Spain. Crop-water requirements for the 2009 
irrigation season were computed from $\mathrm{ET}_{0}$ estimates (following Penman- Monteith) and crop coefficients. NIR was determined using equation 2; $\mathrm{ET}_{0}$ and $\mathrm{EP}$ were computed from the SIAR- Candasnos meteorological data. Values of $\mathrm{K}_{\mathrm{c}}$ were estimated for corn using the thermal units methodology proposed by Martínez-Cob (2008). This methodology shows very good results compared with weighting lysimeters determination in the Ebro Valley region. For stone fruits values of $\mathrm{Kc}_{\mathrm{c}}$ and $\mathrm{K}_{\mathrm{RDI}}$ were established according to Martinez-Cob (2004) and Chalgaf (2008), respectively, for the same area of study. For alfalfa the methodology of FAO 56 was used to establish Kc values for each cut. Evett et al. (2000), illustrate that the FAO 56 methodology applied for alfalfa crop gives good result by comparison with lysimeters studies in a semi arid area (Bushland, TX). For each alfalfa plot the cutting dates, number of cuts and irrigation dose were obtained by analyzing the telecontrol data. FAO 56 methodology was also used to establish Kc for winter cereals and other herbaceous crops. For all of the studied crops, the net irrigation requirement (Equation 2) was obtained as the difference between crop evapotranspiration $\left(\mathrm{ET}_{\mathrm{c}}\right)$ and effective precipitation $(\mathrm{EP})$. Effective precipitation (EP) was calculated from the real precipitation according to the SCS method of the USDA (Cuenca 1989). EP is about the $75 \%$ of the precipitation recorded by the rain gauge (Martinez-Cob, 2004). For corn, monthly cumulative net irrigation requirements were established for May, Jun, July and August. For alfalfa, cumulative NIRs were obtained for each individual cut. Last, cumulative NIR were established for each FAO phase of stone fruit.

$$
\mathrm{NIR}=\left(\mathrm{KC}^{*} \mathrm{ET}_{0}\right)-\mathrm{EP}
$$

The NIR was compared to the irrigation depth (ID) by determining the cumulated SIPI of different periods and crops. For stone fruits, the irrigation water supply, which was obtained from the telecontrol data, was compared to the standard net irrigation requirements (NIR, Equation 2) and to the net controlled deficit irrigation requirements (NCDIR, Equation 3). 
The NCDIR represents the minimum net irrigation requirement of fruit trees that maintains good vegetative development and does not affect the fruit quality or production of the orchard (Gelly et al. 2004). Cumulated SIPI values of the FAO crop phases for the two irrigation strategies (standard and controlled deficit) were calculated.

$$
\mathrm{NCDIR}=\left(\mathrm{Kc}^{*} \mathrm{Krd}^{*} \mathrm{ET}_{0}\right)-\mathrm{EP}
$$

Where $\mathrm{Krd}$ is the reduction coefficient of controlled deficit irrigation and is variable throughout the crop cycle (Chalghaf 2008).

\section{Characterization of Irrigation Patterns}

To identify differences between irrigation systems, the telecontrol data were also analyzed. Namely, for pivot irrigation systems, the total number of irrigation events, irrigation time per event and time interval between irrigations, seasonal irrigation depth and differences in irrigation schedules throughout the crop season were evaluated. The irrigation time was calculated as the duration of continuous hydrant operation, and the time interval between irrigations was computed as the non-operative hydrant time between two consecutive operations. The pivot rotation period was difficult to ascertain from the telecontrol data because most of the irrigation times represent several concatenated pivot cycles.

For solid set irrigation systems, the total number of irrigation events, irrigation time per event and time interval between irrigations, seasonal irrigation depth and differences in irrigation schedules throughout the crop season were determined. Differences in irrigation schedules throughout the crop season were analyzed by comparing the irrigation time per event and the time between two consecutive irrigations in two different periods (from May to June and July to August).

Because a significant number of hydrants were operated in 2009 (290), several solid set (10) and pivot (15) hydrants were selected for further analysis. Pivots were selected to represent different crops, irrigation configurations (formation of a complete circle, semi-circle and $3 / 4$ of 
a circle) and irrigated areas. In addition, ten solid set hydrants were selected to represent different types of crops and irrigated areas. The irrigation schedule of solid set and center pivots for the same type of crop was compared.

The telecontrol data for drip irrigation were analyzed to determine the total irrigation time, irrigation time per event, and time interval between irrigations, seasonal irrigation depth and differences in irrigation schedules throughout the crop season. Four drip irrigation hydrants were selected to represent differences on plot and hydrant sizes. The four plots were managed by different farmers to analyse different irrigation management .

The telecontrol system of the CID provides data from hydrants that correspond to the farm level. Since the water flow of the hydrants were not enough to irrigate all the farm acreage at the same time with an adequate pressure, the irrigation system was divided in several irrigation blocks that irrigate sequentially. Since the telecontrol system rises to the hydrant level, the sequence of the irrigation blocks was unknown. Ten solid set plots $(8$ corn plots and 2 alfalfa plots) were monitored to determine the block irrigation sequence. A pressure logger (Dixon PR300) was installed in the middle of the sprinkler riser in a representative block of each monitored plot, and data were recorded every 15 min. The monitored block was similar to the other hydraulic blocks within the same plots with respect to the irrigation schedule. Data collected from the pressure logger were used to analyze the duration and number of irrigations, characterize daily and nightly irrigation, and determine the irrigation pressure throughout the irrigation season at the block scale. In addition, the pressure, nozzle size of the sprinklers, and the spacing and duration of each irrigation event were used to calculate the irrigation depth. 


\section{Results and Discussion}

\section{The Candasnos Irrigation District}

According to the 2009 ADOR database, the principal crops in the CID were corn $(42.6 \%$, 2,445 ha) and alfalfa $(20 \%, 1,150$ ha). Table 1 presents the percent area, number of hydrants and average seasonal irrigation depth of the crops during the 2009 irrigation season and SIPI. The third most common crop in the study region was stone fruits $(7 \%)$, which corresponded to the total drip-irrigated area. Compared to neighbouring irrigation districts, a large area of the CID was devoted to corn during the 2009 irrigation season because the energy cost of irrigation was nonexistent. In Spain and other developed countries, agriculture consumes large amounts of energy. For instance, in Spain, agricultural energy use accounts for $4.5 \%$ of the total energy use. In particular, the energy consumption of agricultural machinery and the application of irrigation accounts for approximately $70 \%$ of the total agricultural energy use (IDAE 2005). Because the input costs for corn production increase by nearly $50 \%$ due to cost of pumping water, the CID obtains a larger net margin for cropping corn (and other crops) than the neighbouring irrigation districts.

Of the total area, $20 \%$ was not equipped with irrigation systems at the plot level. In Table 1, this area is referred to as no equipped. Alternatively, 2,344 ha were equipped with solid set, 1,838 ha with center pivots and 414 ha possessed drip irrigation systems. For most crops (except winter cereals), the variability in the irrigation depth (expressed as the variation coefficient in Table 1) between plots of the same crop was less than $30 \%$. The extreme variability in the irrigation depth of wheat was due to the low number of wheat plots included in the study (3 plots). Also, Lorite et al. (2004b) studied an irrigation district located in southern Spain and demonstrated that rainfed crops (as wheat and barley) show high variability in the irrigation depth (67\% to $130 \%)$. The variability in the CID was lower than that of neighbouring districts such as the Montesnegros irrigation district, which presented 
variability values of 50\% (Zapata et al. 2009), or the Loma de Quinto de Ebro irrigation district which displayed variability values between 30 and 40\% (Dechmi et al. 2003a). The variability between plots was indicative of different hydrant capacities, number of irrigating blocks and farmer scheduling practices. The variability of irrigation depth, for the same crop, due to farmer scheduling indicated that irrigation water management practices in the CID can be improved substantially (Fernandez et al. 2007).

The alfalfa yield in the district varies from $10,500 \mathrm{~kg} \mathrm{ha}^{-1}$ to $15,500 \mathrm{~kg} \mathrm{ha}^{-1}$ with an average of $14,000 \mathrm{~kg} \mathrm{ha}^{-1}$. The corn yield varies from $11,000 \mathrm{~kg} \mathrm{ha}^{-1}$ to $14,500 \mathrm{~kg} \mathrm{ha}^{-1}$ with an average of 13,000 kg ha-1 (CITA-CHE, Unpublished data from 2009 irrigation season).

Soils in the CID showed spatial variability in the total available water (TAW) from a minimum of $42 \mathrm{~mm}$ ( 230 ha with a TAW between 42 to $60 \mathrm{~mm}$ ) to a maximum of $275 \mathrm{~mm}$ (190 ha with TAW between 200 to $275 \mathrm{~mm}$ ), with an average of $148 \mathrm{~mm}$. These values of TAW did not present significant limitations for pressurized irrigation systems, which provide an important control on applied irrigation dose.

The three main textural classes in the CID were loam, silt-clay-loam and silt-loam. All the soils were characterized by a low percentage of clay with respect to the percent silt, medium texture and good infiltration. In general, soil texture did not affect sprinkler irrigation management.

\section{The Seasonal Irrigation Performance Index for Corn, Alfalfa and Stone Fruits.}

SIPI values for the 2009 irrigation season (Table 1) ranged from $79 \%$ (forage) to $131 \%$ (barley), and a crop seasonal average of $94 \%$ was observed in the CID. In general, the SIPI of stone fruits was greater than $100 \%$, indicating that the application of deficit irrigation strategies is common in the CID. For winter cereals, the SIPI values were indicative of deficit irrigation practices. Alfalfa and corn presented average SIPI values of $107 \%$ and $83 \%$, respectively, indicating that alfalfa was deficit irrigated and corn was adequately irrigated. 
These data suggest that farmers try to optimize water use by restricting application on drought resistant crops (sunflower and alfalfa) and limiting water stress on drought sensitive crops (corn).

The monthly evolution of the cumulative SIPI of corn in 2009 (Figure 2) indicated that the proportion of corn plots with low SIPI values $(<80 \%$, over-irrigated) increased from the beginning of the crop season (May $=25.8 \%$ of the area) to July ( $40.5 \%$ of the area) and then decreased to $26.3 \%$ of the total area at the end of the season. As previously mentioned, telecontrol communication errors occurred on a remote unit of irrigation line TPN1. As a result, data for $19.2 \%$ of corn cropped area could not be obtained throughout the corn season (represented as no data in Figures $2 \mathrm{a}, 2 \mathrm{~b}, 2 \mathrm{c}$ and $2 \mathrm{~d}$ ). Nevertheless, data on the seasonal irrigation depth of the total irrigated area were available because they were manually collected by the district manager. Figure 2, shows the seasonal analysis of the SIPI of the entire corn-cropped area. For corn, light and frequent irrigations were applied in the early stages of crop development to promote germination and to avoid the formation of a crust on the soil surface, which is common in the study area. Excess water applied in June and July ( $41 \%$ of the analyzed area presented a SIPI lower than $80 \%$ ) was partially compensated by low irrigation levels in the final phases of plant growth. Namely, at the end of the irrigation season, $26 \%$ of the area presented a SIPI lower than $80 \%$ and $56 \%$ of the area presented a SIPI between $80 \%$ and $100 \%$. Most of the over-irrigated plots at the end of the season (dark colored plots in Figure 2e) were attributed to persistent over-irrigation throughout the crop season (dark colored plots in Figures $2 \mathrm{a}, 2 \mathrm{~b}, 2 \mathrm{c}$ and $2 \mathrm{~d}$ ). These plots would benefit from an advisory service based on telecontrol data analysis.

For alfalfa, the average SIPI was $107 \%$, indicating that general deficit -irrigation was applied to this crop during the 2009 irrigation season. Table 2 presents the area of alfalfa according to the SIPI value. The analysis was performed for the entire season and each of the four individual cuts. The results indicated that $46.2 \%$ of the total area displayed a seasonal SIPI 
value greater than $100 \%$ (Table 2), suggesting that the supply of irrigation water was lower than the calculated irrigation requirements. Alternatively, $45.5 \%$ of the total area displayed a SIPI value between $80 \%$ and $100 \%$, which is indicative of adequate irrigation management. Only $8.3 \%$ of the total area presented a SIPI value less than $80 \%$, which is indicative of overirrigation. In general, the seasonal SIPI analysis revealed that the dose of applied irrigation was lower than the seasonal crop water requirements. Moreover, the SIPI values of individual cuts (Table 2) displayed an interesting pattern. Namely, for all of the individual cuts, the greatest proportion of alfalfa displayed SIPI values greater than $120 \%$ (accounting for $24 \%$ of the second cutting to $42 \%$ of the first cutting), which is indicative of deficit irrigation. The high percentage of area that presented deficit irrigation strategies for the alfalfa crop was surprising. It has to be noted that the initial soil water content was not considered in the analysis and could introduce some noise, especially for the first and second alfalfa cuttings. In any case, a revision of alfalfa crop water requirements as proposed by FAO 56 to local conditions is suggested from these results.

Although there are not available crop yields data associated to irrigation dose and schedule at farm level, the large variability of irrigation dose and the adequate average yield of the principal crops in the district, indicate an important potential for improvement of water use. Figure 3 shows the weekly evolution of the applied irrigation depth, net irrigation requirements (NIR) and net controlled deficit irrigation requirements (NCDIR) for four medium cycle peach plots. The studied plots were selected by their differences in size and management (different farmer). In the four plots, the amount of applied irrigation was lower than the standard NIR throughout almost all of the irrigation season. The two plots presented in the upper portion of Figure 3 (3a and 3b which correspond to hydrants VH097 and VH100, respectively) indicated that deficit irrigation strategies were applied until harvest (beginning of August). However, after harvest, a standard irrigation strategy was applied. Alternatively, the two plots in the lower portion of Figure 3 (3c and $3 d$, which 
correspond to hydrants $1 \mathrm{H} 141$ and $1 \mathrm{H} 139)$ indicated that deficit irrigation strategies were conducted throughout the entire irrigation season. Table 3 presents the SIPI of standard irrigation strategies, irrigation depth and the SIPI of controlled deficit irrigation strategies for 16 hydrants used to irrigate medium cycle peaches. The data are presented according to the four FAO phases. The average difference between the standard NIR and the applied irrigation depth for medium maturing peaches was approximately $15 \%-27 \%$. However, for both standard and deficit irrigation strategies, extremely high SIPI values were observed during the initial crop development phase. Telecontrol data were analyzed from May onward and most probably the orchards were irrigated in March and April (data not available), also the initial soil water content was not considered in the analysis. Namely, hydrants 2H138, 1H059, 1H080 and VH058 corresponded to recently planted orchards; thus, the extremely high standard and controlled deficit SIPI values were attributed to low irrigation doses on young orchards. Except for VH097 and VH100 (Figure 3a and 3b, respectively), the remaining hydrants displayed standard SIPI values greater than $100 \%$, which suggested that deficit irrigation strategies were performed on medium cycle peaches at the CID. Seasonal SIPI values of plots irrigated according to the CDI strategy were approximately 100\% (except for VH097 and VH100) or higher, indicating that the total applied irrigation was similar or lower to the NCDIR. However, based on the SIPI values of the four FAO phases, the current irrigation strategy was not in accordance with the CDI strategy. Specifically, irrigation water reductions remained constant throughout peach development (sustained deficit), and the CDI strategy recommends water reductions at specific phases of the crop cycle. According to Gelly et al. (2004), the recommended phases of CDI are pit hardening (stage II of fruit growth) and postharvest. When the same amount of water is applied, the CDI is superior to sustained deficit irrigation in peach production (Fereres and Soriano, 2007). The CDI technique is based on the diverse sensitivity of the plant to water stress during different phenological crop stages. Intermittent water deficits during 
specific periods can increase the efficiency of irrigation, which saves irrigation water and improves harvest quality (Chalmers et al. 1981; McCarthy et al. 2002; Loveys et al. 2004; Cameron et al. 2006). Again, telecontrol data continuous analysis can be an important tool for promoting and facilitating CDI strategies in stone fruits.

Within irrigated areas in Spain, Faci et al. (2000) found that the Almudevar irrigation district in the Ebro Basin (surface irrigation) presented an average SIPI of 70\%, which is indicative of over-irrigation. Alternatively, Stambouli (2008) found that an irrigated area within the Las Filadas gully watershed (Huesca, Spain) possessed an average SIPI of 97.2\% (similar to the average SIPI of the present study), which indicated that good irrigation management practices were conducted. However, sensible crops such as corn and rice were over-irrigated (SIPI values of $77 \%$ and $68 \%$, respectively), and resistant crops such as barley and sunflower (SIPI values of $111 \%$ and $172 \%$, respectively) were deficit -irrigated. In contrast, Dechmi et al. (2003a) studied another sprinklers irrigation district in the Ebro Valley region and found that the average SIPI value of the crops was $127 \%$ (indicative of deficit -irrigation). Lorite et al. (2004 a,b) determined the ARIS ratio (annual volume of irrigation water inflow/annual volume of crop irrigation demand) of the Genil Cabra irrigation scheme (southern Spain) and demonstrated that the average ARIS of the total area was less than 1 (from 0.45 in 1996-1997 to 0.64 in 1998-1999), indicating that irrigation applications did not meet the maximum ET demand. In general, average ARIS values for different irrigation areas around the world (Kloezen and Garcés 1998; Molden et al. 1998; Burt and Styles 1999) are higher than those obtained by Lorite et al. (2004a). This discrepancy was attributed to crop variability, irrigation methods, socio-economic conditions and the definition of ARIS, which varies slightly from author to author. 


\section{Characterization of Irrigation Patterns.}

In the CID 1,838 ha were irrigated by pivots. The minimum, maximum and mean pivot sizes in the CID were 4 ha, 80 ha and 22 ha, respectively; thus, high variability in pivot sizes was observed $(\mathrm{VC}=63 \%)$. Major crops irrigated by central pivots include corn, alfalfa and double crops, which cover 1,080 ha, 573 ha and 64 ha, respectively. Fifteen representative pivots were selected to study the irrigation patterns of pivot irrigation systems in the CID. The studied pivots summarize the variability in crop, size, inflow rate and shape of the district pivots.

Table 4 presents the crop, hydrant denomination, irrigated area, pivot diameter, flow, irrigation time (h ha-1 event-1) and interval between irrigation events of the selected pivots. The last two variables were computed for two periods (from May to June and July to August). For comparative purposes, the irrigation time was expressed in hour per hectare and event. Because the irrigation time and the water flow differs between pivot points, the irrigation time presented in Table 4 represents the average irrigation time per hectare at identical water flow rates.

Differences in irrigation time per event among plots of the same crop were typically accompanied by differences in intervals between irrigation events. In general, the irrigation time per event was greater for alfalfa than corn (from 1.27 to $15.63 \mathrm{~h} \mathrm{ha}^{-1}$ event-1 $^{-1}$ for alfalfa and from 0.42 to $6.78 \mathrm{~h} \mathrm{ha}^{-1}$ event $^{-1}$ for corn). Moreover, the time between irrigations was larger for alfalfa. Most of the pivots irrigated several concatenated cycles between July and August, as indicated by the high irrigation time per hectare and event (Table 4). In general, the irrigation time increased from May-June to July-August. For hydrant 2H148 cropped with corn the irrigation time and the interval between irrigations remain constant throughout the irrigation season, indicating that the farmer did not modify the irrigation schedule. For hydrants 2H106 and 2H094, the irrigation time remained constant throughout the crop cycle; however, the interval between irrigations decreased from May-June to July- 
August. Figure 4 presents the change in the irrigation time in hours per hectare and event, and the change in the irrigation interval throughout the crop cycle. Figures $4 \mathrm{a}$ and $4 \mathrm{~b}$ correspond to hydrants 1H003 and VH017, respectively, cropped by alfalfa. Figures 4c and 4d correspond to hydrants $1 \mathrm{H} 069$ and 2H018, respectively, cropped by corn.

Alfalfa pivot VH017 irrigated continuously from July to August and was only stopped to perform the cuttings (8.6 days in the cutting period, on average, Figure $4 \mathrm{~b}$ and Table 4 ). Pivot 1H069, which was cropped with corn, followed the same irrigation pattern (Figure 4c). In this case, the low hydrant flow related to the size of the plot, forced the hydrant to irrigate almost continuously from July to August (the period of maximum irrigation requirements for corn). Even then, the irrigation dose $(533 \mathrm{~mm})$ was relatively low compared to the net water requirements for corn $(648 \mathrm{~mm})$. Alfalfa hydrant 1H003 (Figure 4a) showed four large irrigation intervals (from 9 to 15 days) corresponding to the dates between cuts. The irrigation time also varied throughout the alfalfa season, indicating that the farmer frequently modified the irrigation schedule.

Corn hydrant $2 \mathrm{H} 018$ (Figure $4 \mathrm{~d}$ ) presented an irrigation pattern consisting of light (1 to 1.5 hours of irrigation per hectare and event) and frequent (an irrigation interval of 1.5 to 2.5 days) irrigations from the beginning of the season to the end of June. The light irrigation change to continuous irrigation (15 to 43 hours of irrigation per hectare and event) between the beginning of July to the middle of August. With corn pivots, most farmers apply light and frequent irrigations until the end of June to avoid crust formation. Alternatively, from the middle of July to the middle of August, the pivot was operated almost continuously for 10 to 15 days (depending on the relationship between the size of the pivot and the hydrant flow). From the middle of August to the middle of September, light and frequent irrigations were again applied (Figures $4 \mathrm{c}$ and $4 \mathrm{~d}$ ). Thus, the results indicated that the analysis of pivot irrigation cycles could be used to better understand irrigation management strategies with 
sprinkler irrigation systems. In future studies, pivot movement should be monitored by GPS to establish pivot irrigation cycles.

The solid set was the most common sprinkler irrigation system in the study region (Figure 1). The mean area of solid set plots was 7.5 ha with high variability $(\mathrm{VC}=120 \%)$. The most common sprinkler layout in the CID was triangular. In this configuration, sprinklers are placed in a straight line at $18-\mathrm{m}$ intervals, and the distance between the lines is set to $18 \mathrm{~m}$ (T18x18). In the majority of the plots, the sprinklers were equipped with $4.8 \mathrm{~mm}$ and $2.4 \mathrm{~mm}$ diameter nozzles.

Table 5 presents the telecontrol data analysis of eight of the ten supervised plots (telecontrol data for the other two supervised plots, 1H092 and 1H108, were not available during the season). Moreover, the seasonal irrigation time (hours), seasonal irrigation depth, average irrigation time (expressed in hours per hectare and event) and the mean time between two consecutive irrigations during two representative periods of corn development (May-June and July-August) are also presented in Table 5. For the analyzed crops (alfalfa and corn), the irrigation time increased during July and August, and the irrigation interval decreased with respect to the first period (May-June). Moreover, the irrigation depth of alfalfa was greater than that of corn. Namely, hydrants $2 \mathrm{H} 043$ and 1H062B, which were cropped by alfalfa, presented an irrigation depth of $1350 \mathrm{~mm}$ and $867 \mathrm{~mm}$, respectively. In addition, the alfalfa plots presented the largest seasonal irrigation time (1924 hours and 1957 hours). For hydrant $2 \mathrm{H} 043$, the irrigation depth was excessively large compared to the alfalfa irrigation requirements for the 2009 irrigation season $(843 \mathrm{~mm})$. In most cases, time between irrigation in the second period were less than one day, which indicated that the capacity of the irrigation network to manage water in the presence of restrictions such as wind was relatively low. Figure 5 presents the irrigation time and irrigation interval of four solid set hydrants throughout the irrigation season. The upper region of Figures $5 \mathrm{a}$ and $5 \mathrm{~b}$ correspond to alfalfa solid set plots (hydrants $2 \mathrm{H} 043$ and 1H062B, respectively), and the lower portion of 
Figures $5 \mathrm{c}$ and $5 \mathrm{~d}$ correspond to corn solid set plots (hydrants VH012 and 2H158, respectively). Hydrant $2 \mathrm{H} 043$ showed a nearly constant irrigation time of 1.8 hours per hectare and event in the beginning of the crop season; however, the irrigation time of hydrant $2 \mathrm{H} 043$ increased to $2.2 \mathrm{~h} \mathrm{ha}^{-1}$ event $^{-1}$ in July and August. The relatively constant irrigation times were suddenly interrupted by abrupt applications of 10 or 18 hours per hectare and event at the beginning of June and the middle of July. For alfalfa, the irrigation interval was nearly constant at 0.25 days and was only interrupted by 4 to 12 -day intervals, which corresponded to the alfalfa cuts. A continuous pattern was also observed for corn (hydrant VH012), as shown in Figure 5c. Specifically, the irrigation time was nearly constant at 1.2 hours per hectare and event throughout the entire corn cycle, except for the beginning of July and the beginning of August. During these time frames, the irrigation time increased to 12 or 25 hours per hectare and event, respectively. The irrigation interval from the middle of June to the end of the corn irrigation season remained constant at 0.33 days. Nevertheless, on some dates, 2 or 3 day intervals between irrigations were observed (probably after insecticide treatment). The results shown in Figures $5 a$ and $5 c$ revealed that the farmer did not frequently alter the irrigation schedule. Alternatively, Figures $5 \mathrm{~b}$ and $5 \mathrm{~d}$ indicated that the farmer continuously modified the irrigation schedule throughout the crop cycle. For instance, as shown in Figure 5b, a continuous variation in the irrigation time per hectare was observed from the end of May to the beginning of August. Specifically, the irrigation time was increased by 2 to 6 hour increments per hectare and event. Finally, two 14 and 12-hour irrigations were performed in August. The irrigation interval presented a more consistent pattern than the irrigation time and was usually less than one day. However, 6 to 12-day intervals were also observed due to the alfalfa cuttings. Figure $5 \mathrm{~d}$ shows the variability in the irrigation pattern of short cycle corn. Significant variability in the irrigation time was observed until the end of August, where the irrigation time increased from 1 to 7 hours per hectare and event. From the end of August to the end of the corn irrigation season, the 
irrigation time remained constant at 1 hour per hectare and event. Alternatively, from the beginning of July to the end of the season, the irrigation interval was equal to 0.5 days.

Irrigation times of 10 or 25 hours per hectare and event were obtained from the telecontrol data of the analyzed hydrants (Figure 5). This was a surprising result because soil cannot handle such high irrigation doses. The irrigation data obtained from the pressure transducer installed at the supervised plots clarified these extremely high irrigation times. Table 6 presents the irrigation pressure and irrigation time obtained from the pressure transducer data. Hydrant $2 \mathrm{H} 043$ presented a constant irrigation time of 1.9 hour per hydraulic block and event throughout the entire alfalfa cycle, without regard to the abrupt increase in irrigation time (Figure 5a). Thus, when the block sequential irrigation cycles were concatenated, the hydrant counter did not stop, and the irrigation time was accumulated by the telecontrol system. The irrigation time measured by the pressure transducer at the nozzle of one block was the same as the irrigation time of the telecontrol data; however, a series of irrigations (2 hours) and cessations (22 hours to irrigate the others eleven blocks) were observed. The discrepancy between the telecontrol and pressure transducer data of hydrant 2H043 was also observed in the other analyzed hydrants (differences between Table 5 and Table 6). Moreover, the differences in the irrigation patterns between plots obtained from the telecontrol data analysis were significantly larger than that of the pressure transducer data. In addition, significant differences between the telecontrol and pressure transducer data were observed for hydrant $1 \mathrm{H} 014$. The pressure transducer showed a constant irrigation time of 1 hour throughout the corn cycle (Table 6), whereas the telecontrol data showed an irrigation time of almost 3 hours from May-June and 5 hours from July-August (Table 5). Again, the concatenation of block sequential irrigation cycles showed a different irrigation pattern. Differences in irrigation management are important because short and frequent sprinkler irrigation (as shown in the ten supervised plots) yield high evaporation losses from crop intercepted water (independent of irrigation time, Wang et al. 2006; Mauch et al. 2008). 
However, short and frequent irrigation applications can be an alternative for problematic soils. The soils in the study region did not present significant water retention and runoff problems; thus, irrigation management could be improved by increasing the irrigation time per block and event.

The low variability of the pressure at the nozzle point (the variation coefficient was less than $5 \%)$ between irrigations indicated that the seasonal variation in the collective network demand did not affect the hydrodynamics of the individual plot network. Thus, the regulating valves at the hydrant points worked adequately. Nevertheless, significant differences in the irrigation pressure were observed between plots, and the pressure ranged from $243 \mathrm{kPa}$ to $438 \mathrm{kPa}$. The lowest irrigation pressures were at the lower limit of the suggested pressure of the current sprinkler layout (T18x18). Alternatively, the largest irrigation pressures were excessively high and self-defeating in windy areas.

On-plot supervision provided the necessary data to determine if irrigation was conducted during the day or night. The results indicated that three-quarters of the irrigations in the monitored blocks of plots 1H002 and 2H100 were applied during the day. Alternatively, in the blocks of hydrants 2H158, 2H124 and VH012, three-quarters of the irrigations were applied at night. Preferences for daily or nightly irrigation indicated that the block irrigation sequence of the plots was not periodically modified. Irrigation schedules based on nightly irrigation may be superior in the Ebro Valley region because the night-time WDEL is onehalf of daytime losses (Playán et al. 2005). In hydrants 1H014, 2H043, 1H108 and 1H092, the irrigation time was equally divided between the day and night. This type of irrigation pattern requires periodic changes in the irrigation schedule; however, according to Dechmi et al. (2004) is more efficient than fixed block sequence irrigation.

Table 7 presents the telecontrol data of four drip-irrigated plots. In general, the seasonal irrigation time was related to the continuous inflow rate of the hydrant, which was expressed in liters per second and hectare. The lowest seasonal irrigation time (1,026 hours) 
corresponded to the highest continuous inflow rate $\left(1.9 \mathrm{l} \mathrm{s}^{-1} \mathrm{ha}^{-1}\right)$, which was observed in hydrant VH100. The irrigation interval was always lower than one day; thus, the orchards were irrigated at least once per day. The irrigation time per hectare and event varied from half an hour to 4 hours per hectare and event. Moreover, the average values presented in Table 7 did not show temporal variability in irrigation scheduling. Figure 6 presents the temporal variability of the irrigation patterns of the four selected hydrants. Hydrants 1H141 and $1 \mathrm{H} 139$ (Figures $6 \mathrm{a}$ and 6b, respectively) presented greater variability in the irrigation time throughout the entire peach cycle than hydrants VH100 and VH097 (Figures 6c and 6d, respectively). Namely, the irrigation schedule of hydrants 1H141 and 1H139 was changed almost weekly. For hydrants VH100 and VH097, the irrigation time increased more (VH097) or less (VH100) gradually with fruit development and decreased drastically at postharvest. However, the irrigation interval remained constant at less than one day and slight variations were observed throughout the crop development process.

\section{Comparison of irrigation patterns between solid sets and pivots.}

The principal difference in the irrigation scheduling patterns of solid set and center pivots was the number of opening and closing of the hydrants (irrigation events). For solid sets, the number of irrigation events during a crop season increased from 35 to 45 , while the number of events for pivots was reduced to 10-20. Consequently, the irrigation time per hectare and event was larger for pivots than solid sets. The results of the on-farm irrigation analysis of the 10 solid sets revealed that the irrigation events should be obtained from the irrigation block sequence data. For pivots, telecontrol data analysis was biased because the pivot cycle times were not available and the complete irrigation sequence could not be established.

The average applied irrigation depths at the CID were $808 \mathrm{~mm}$ and $793 \mathrm{~mm}$ for pivots and solid-set systems, respectively, and significant differences between systems were not observed. In contrast, the seasonal applied irrigation depth of alfalfa was significantly 
different among sprinkler irrigation systems. Namely, the solid set system provided an average seasonal irrigation depth of $889 \mathrm{~mm}$ (with a standard deviation of $164 \mathrm{~mm}$ ), and the pivot system provided an average irrigation depth of $793 \mathrm{~mm}$ (standard deviation of 120 $\mathrm{mm})$. For corn, significant differences in the average irrigation depth between irrigation systems were not observed ( $819 \mathrm{~mm}$ for solid sets and $818 \mathrm{~mm}$ for pivots). In any case, for both systems, the variability of the applied doses was high (standard deviation of $182 \mathrm{~mm}$ and $225 \mathrm{~mm}$ for solid sets and pivots, respectively). For alfalfa, the irrigation depth of pivot plots was lower than that of solid sets due to the greater efficiency of pivot systems. Pláyan et al. (2005) demonstrated that water losses in sprinkler irrigation systems (pivots and lineal moves) were two-thirds lower than that of solid set systems. Dechmi et al. (2003b) studied the Loma de Quinto irrigation district of the Ebro Valley and found that the Christiansen coefficient of uniformity (CU) of center pivots (76\%) was greater than that of solid-sets $(68 \%)$. However, in the Loma de Quinto, solid set designs were deficient for windy areas. 


\section{Conclusions}

Variability in the irrigation depth among plots of the same crop was approximately $25 \%$. This variability was mainly attributed to differences in the irrigation schedule.

The seasonal SIPI values of the crops at the CID indicated that the farmers try to optimize irrigation water use by restricting applications on drought resistant crops (SIPI values greater than $100 \%$ were observed for sunflowers and alfalfa) and limiting water stress in drought sensitive crops (the average SIPI value of corn was $83 \%$ ). Irrigation was also restricted in drip irrigated stone fruit orchards.

The monthly change in the cumulative SIPI of corn indicated that the area of corn with low SIPI values $(<80 \%)$ increased from the beginning of the crop season to July and then decreased at the end of the season. Frequent and light applications are often conducted at the early stages of crop development to avoid crusting problems and to promote corn germination. In general, over-irrigated plots at the end of the season were attributed to persistent over-irrigation throughout the growing season. Thus, over-irrigated plots would benefit from an advisory service based on telecontrol data analysis.

For alfalfa, the average SIPI was 107\%, which was indicative of a general deficit -irrigation pattern. Moreover, the results suggested that deficit -irrigation was repeated every cutting cycle. Namely, $82 \%$ of alfalfa plots presented SIPI values greater than $80 \%$. As previously mentioned, SIPI values greater than the potential efficiency of the irrigation system are indicative of deficit -irrigation. Thus, the alfalfa would benefit for a telecontrol data continuous analysis following the proposed methodology. Again, the telecontrol data can be an important tool for the improvement of irrigation water management in alfalfa.

The SIPI values of stone fruits throughout the four FAO phases suggested that deficit irrigation strategies were performed on medium cycle peaches at the CID. However, the applied irrigation dose was continuously reduced throughout the crop cycle (sustained 
deficit), and the reductions were not applied at the recommended phases (controlled deficit); thus, the applied irrigation strategy was not based on a controlled deficit strategy.

The analysis of temporal variability of SIPI values is a valuable tool for the improvement of irrigation water management for corn, alfalfa and stone fruit at plot level. Real time SIPI analysis from telecontrol data as proposed in this research, complemented with the control of some on-farm block irrigation sequences should be implemented in the daily routines of the district office to greatly improve the irrigation management at plot level. This methodology could be easily implemented in any telecontrolled irrigation network. However, the reliability and accuracy of the methodology to determine the crop water requirements of the main crops of the CID is a key factor in the estimation of the seasonal irrigation performance indexes (SIPI) since the real values of the net irrigation requirements affect directly the SIPI values. Consideration of the NIR spatial variability along the CID also could improve the irrigation water management at plot level. This objective will require a characterization of the spatial distribution of crop water requirements.

The general irrigation patterns of solid set and center pivot systems indicated that the irrigation time per event for alfalfa was greater than that of corn. Furthermore, the short and frequent irrigation timing for corn (1-1.5 hours per block and event) could yield high evaporation losses from crop intercepted water. In general, two different patterns in the irrigation times were observed at the CID. In the first irrigation pattern, short irrigations were applied until the middle of June. Subsequently, the irrigation time was increased until the middle of August and then decreased until the end of the crop season. This irrigation pattern was employed by farmers that did not frequently alter the irrigation schedule (low intervention). Alternatively, the second pattern was characterized by continuous changes in the irrigation time throughout the crop season. This type of pattern requires significant farmer intervention because the irrigation schedule is changed almost weekly. The second irrigation pattern was observed more often with solid set systems than pivots; however, 
differences in the irrigation performance among the two irrigation patterns could not be established. Nevertheless, the analysis of telecontrol data is an important tool for the improvement of irrigation management in pressurized irrigation districts and can be used to promote and facilitate controlled deficit irrigation strategies on stone fruits. Telecontrol data can be a valuable tool to reduce variability of irrigation water management between plots. 


\section{Acknowledgements}

We applied the sequence-determines-credit approach for the sequence of authors. This research was funded by the MCINN of the Government of Spain through grants AGL2007-66716-C03-01/02, AGL2010-21681-C03-01/03; the European Commission through grant QUALIWATER (INCO-CT2005-015031) and by the FPI-MICINN PhD grants program. The authors would like to thank the support provided by Mr. Antonio Ferrer Millán (District Manager) and by the farmers of the Candasnos Irrigation District. Thanks are particularly due to our field staff: Miguel Izquierdo, Jesus Gaudó, Juan Manuel Acín and Ricardo Santolaria. 


\section{References}

Allen RG, Pereira LS, Raes D, Smith D (1998). “Crop evapotranspiration. Guides for computing crop water requirements". FAO Irrig. Drain. No 56. Italy, 300 p.

Burt CM, Clemmens AJ, Strelkoff TS, Solomon KH, Bliesner RD, Hardy LA, Howell TA, Eisenhauer DE (1997). "Irrigation performance measures: efficiency and uniformity". J. Irrig. Drain. Engrg. 123 (6), 423-442.

Burt CM, Styles SW (1999). "Modern water control and management practices in irrigation. Impact on performance". (Water Reports 19) FAO, Rome.

Chalmers DJ, Mitchell PD, van Heek L (1981). "Control of peach tree growth and productivity by regulated water supply, tree density, and summer pruning". J. Am. Soc. Hort. Sci. 106, 307-312.

Cameron RWF, Harrison-Murray RS, Atkinson CJ, Judd HL (2006). "Regulated deficit irrigation: a means to control growth in woody ornamentals". J. Hort. Sci. Biotechnol. 81 (2006), pp. 435-443.

Chalghaf B (2008). “Análisis del uso del agua de riego en una explotación comercial de frutales de hueso del valle medio del Ebro". Thesis Master of Science IAMZ. Unpublished

Clemmens AJ, Burt CM (1997). “Accuracy of Irrigation Efficiency Estimates”. J. Irrig. Drain. Engrg. ASCE 123(6): 443-453.

Cuenca RH (1989). “Irrigation System Design: An Engineering Approach”. PrenticeHall Inc., Englewood Cliffs, NJ, USA, 552 pp.

Damas M, Prados AM, Gómez F, Olivares G (2001). “Hidrobus® system: Fieldbus for integrated management of extensive areas of irrigated land". Microproc and Microsys 25(3): 177-184.

Dechmi F, Playán E, Cavero J, Faci JM, Martinez-Cob A (2003a). “Wind effects on solid set sprinkler irrigation depth and yield of maize (Zea mays)". Irrig. Sci. 22: 6777.

Evett, S.R., Howell T.A., Todd, R.W. Schneider, A.D. and Tolk J.A. (2000) Alfalfa reference ET measurement and prediction. Pp. 266-272 In Robert G. Evans, Brian L. Benham, and Todd P. Trooien (ed) Proceedings of the 4th Decennial National Irrigation Symposium, Nov. 14-16, Phoenix, AZ.

Dechmi F, Playán E, Faci J, Tejero M (2003b). “Analysis of an irrigation district in northeastern Spain. I: Characterisation and water use assessment". Agric. Water Manage. 61, 75-92.

Dechmi F, Playán E, Cavero J, Martínez-Cob A, Faci JM (2004). “Coupled Crop and Solid Set Sprinkler Simulation Model. II: Model Application”. J. Irrig. Drain. Engrg 130(6): 511-520

Faci JM, Bensaci A, Slatni A, Playán E (2000). “A case study for irrigation modernisation: I. Characterisation of the district and analysis of water delivery records". Agric. Water Manage. 42, 315-336.

Fereres E, Soriano MA (2007). “Deficit irrigation for reducing agricultural water use". J. of Exp. Bot. 58: 147-159.

Fernández MD, González AM, Carreño J, Párez C, Bonachela S (2007). “Analysis of on-farm irrigation performance in Mediterranean greenhouses". Agric Water Manage. 89, 251-260. 
Forteza del Rey V (2002). “El plan nacional de regadíos”. Agricultura 842: 554-556.

Gelly M, Recasens I, Girona J, Mata M, Arbones A, Rufat J, Marsal J (2004). “Effects of stage II and postharvest deficit irrigation on peach quality during maturation and after cold storage". J. Sci. Food Agric., Volume: 84, Issue: 6, Pages: 561-568,

Published: APR 302004.

Kloezen WH, Garcés C (1998). “Assessing irrigation performance with comparative indicators: the case of the Alto Rio Lerma irrigation district, Mexico". (Research Report 22) Irrigation Water Management Institute, Colombo, Sri Lanka (IWMI). v, 39p.; 42p.

Lecina S, Playán E, Isidoro D, Dechmi F, Causapé J, Faci JM (2005). “Irrigation evaluation and simulation at the Irrigation District V of Bardenas (Spain)". Agric. Water Manage. 73 (3): 223-245.

Lorite IJ, Mateos L, Fereres E (2004a). “Evaluating irrigation performance in a Mediterranean environment: I. Model and general assessment of an irrigation scheme". Irrig. Sci., 23 (2), 77-84.

Lorite IJ, Mateos L, Fereres E (2004b). "Evaluating irrigation performance in a Mediterranean environment. II: Variability among crops and farmers". Irrig. Sci., 23 (2), 85-92.

Loveys BR, Stoll M, Davies WJ (2004). "Physiological approaches to enhance water use efficiency in agriculture: exploiting plant signalling in novel irrigation practice". In: Bacon (Ed.), Water Use Efficiency in Plant Biology. Blackwell Publishing Ltd, Victoria Australia, pp. 113-141.

Malano H, Burton M, (2000). "Guidelines for Benchmarking Performance in the Irrigation and Drainage Sector". IPTRID Secretariat, FAO, Rome. 50p.

Martínez -Cob, A. (2004). “Revisión de las necesidades hídricas netas de los cultivos de la cuenca del Ebro". 111 pp. Documento interno CHE. Inédito (In Spanish).

Martínez-Cob A (2008). "Use of thermal units to estimate corn crop coefficients under semiarid climatic conditions". Irrig. Sci. 26 (4): 335-345.

Mauch KJ, Delgado JA, Bausch WC, Barbarick K, McMaster G. (2008). "New weighing method to measure shoot water interception". J. Irrig. Drain. Engrg. -ASCE 134(3): 349-355.

McCarthy MG, Loveys BR, Dry PR, Stoll M (2002). “Regulated deficit irrigation and partial rootzone drying as irrigation management techniques for grapevines. In: Food and Agricultural Organization of the United Nations (FAO) (ed.)", Deficit Irrigation Practices. Rome, Italy, pp. 79-88.

Molden DJ, Gates TK (1990). "Performance measures for evaluation of irrigationwater-delivery systems". J. Irrig. Drain. Engrg. -ASCE. 116 (6), 804-823.

Molden DJ, Sakthivadivel R, Perry CJ, Fraiture C, Kloezen WH (1998). “Indicators for comparing performance of irrigated agricultural systems". (Research Report 20) International Water Management Institute, Colombo, Sri Lanka. 26p.

Playán E, Salvador R, Faci JM, Zapata N, Martínez-Cob A, Sánchez I (2005). “Day and night wind drift and evaporation losses in sprinkler solid-sets and moving laterals". Agric. Water Manage., 76(3):, 139-159.

Playán E, Mateos L (2006). "Modernization and optimization of irrigation systems to increase water productivity”. Agric. Wat Manage., 80(1-3), 100-116. 
Playán E, Cavero J, Mantero I, Salvador R, Lecina S, Faci JM, Andrés J, Salvador V, Cardeña G, Ramón S, Lacueva JL, Tejero M, Ferri J, Martínez-Cob A (2007). “A database program for enhancing irrigation district management in the Ebro Valley (Spain)". Agric. Wat. Manage. 87, 187-199.

Smith M (1993). "CLIMWAT for CROPWAT, a climatic database for irrigation planning and management". FAO Irrigation and Drainage Paper 49, Rome, 113 pp.

Soil Survey Laboratory (2004). "Methods manual, Soil Survey Laboratory Investigation report $\mathrm{N} 42$ Version 4.0, 735p". Available in: ftp://ftpfc.sc.egov.usda.gov/NSSC/Lab_Methods_Manual/SSIR42_2004_view.pdf

Stambouli T (2008). "Development of an agroenvironmental index for the risk of water pollution by phosphorus in an irrigated area of the Riegos Del Alto Aragón Irrigation Scheme". Master of Science Thesis. Mediterranean Agronomic Institute of Zaragoza (CIHEAM-IAMZ), 170p.

Wang QG, Kang Y, Liu HJ, Liu SP (2006). “Method for measurement of canopy interception under sprinkler irrigation". J. Irrig. Drain. E-ASCE 132(2): 185-187.

Zapata N, Playán E, Skhiri A, Burguete J (2009). "Simulation of a collective solid set sprinkler irrigation controller for optimum water productivity". J. Irrig. Drain. EASCE 135 (1), 13-24. 


\section{List of Tables}

Table 1 Summary of the telecontrol data for the 2009 irrigation season in CID

\begin{tabular}{lcccc}
\hline \multicolumn{1}{c}{ Crop } & $\begin{array}{c}\text { Area } \\
(\mathbf{( \% )}\end{array}$ & $\begin{array}{c}\text { Number of } \\
\text { Hydrants }\end{array}$ & $\begin{array}{c}\text { Average Seasonal } \\
\text { Irrigation Depth* } \\
(\mathbf{m m})\end{array}$ & $\begin{array}{c}\text { SIPI* } \\
\mathbf{( \% )}\end{array}$ \\
\hline No equipped plots & 20 & 81 & - & - \\
Non cropped & 4.7 & 29 & - & - \\
Long cycle Corn & 37.1 & 151 & $822(22)$ & $82(18)$ \\
Short cycle Corn & 5.5 & 31 & $660(27)$ & $92(39)$ \\
Alfalfa & 20 & 54 & $860(17)$ & $107(28)$ \\
Stone fruits & 6.7 & 29 & $565(25)$ & $123(42)$ \\
Wheat & 0.2 & 3 & $194(120)$ & $108(92)$ \\
Barley & 1.5 & 6 & $223(37)$ & $131(57)$ \\
Double crops & 2.9 & 6 & $928(13)$ & $89(12)$ \\
Forage & 1.1 & 8 & $826(16)$ & $79(13)$ \\
Sunflower & 0.3 & 2 & $519(20)$ & $110(22)$ \\
\hline
\end{tabular}

*Average and Variation Coefficient (\%) 
Table 2 SIPI values (\%) of alfalfa computed for the four individual cuts and for the whole season.

\begin{tabular}{lccccc}
\hline \multicolumn{1}{c}{ SIPI (\%) } & \multicolumn{5}{c}{ Area (\%) } \\
& $\mathbf{1}^{\text {st }} \mathbf{c u t}$ & 2 $^{\text {nd }} \mathbf{c u t}$ & 3 $^{\text {rd }} \mathbf{c u t}$ & $\mathbf{4}^{\text {th }}$ cut & Seasonal \\
\hline$<\mathbf{5 0}$ & 1.1 & 0.0 & 0.0 & 1.0 & 0.0 \\
$\mathbf{5 0 - 8 0}$ & 0.6 & 8.3 & 6.1 & 2.1 & 8.3 \\
$\mathbf{8 0 - 1 0 0}$ & 19.4 & 18.5 & 12.8 & 11.3 & 45.5 \\
$\mathbf{1 0 0}-\mathbf{1 2 0}$ & 6.9 & 19.6 & 17.2 & 16.8 & 36.2 \\
$>\mathbf{1 2 0}$ & 42.2 & 23.7 & 34.0 & 38.9 & 10.0 \\
No Data & 29.9 & 29.9 & 29.9 & 29.9 & 0.0 \\
\hline
\end{tabular}


Table 3 Cumulated Irrigation depth (mm), Standard SIPI (\%) and Controlled Deficit SIPI (\%) according to the four FAO phases (Pini, Pdevelop, Pgrowing and Pfinal) for the 16 medium cycle peach hydrants. The SIPI for each crop phase was computed with cumulated data.

\begin{tabular}{|c|c|c|c|c|c|c|c|c|c|c|c|c|}
\hline \multirow{2}{*}{ Hydrants } & \multicolumn{4}{|c|}{ Irrigation depth (mm) } & \multicolumn{4}{|c|}{ Standard SIPI (\%) } & \multicolumn{4}{|c|}{ CD SIPI (\%) } \\
\hline & Pini & Pdevelop. & Pgrowing & Pfinal & Pini & Pdevelop & Pgrowing & Pfinal & Pini & Pdevelop & Pgrowing & Pfinal \\
\hline $1 \mathrm{H} 141$ & 6 & 27 & 351 & 513 & 691 & 304 & 136 & 129 & 691 & 256 & 114 & 106 \\
\hline 1H142 & 4 & 23 & 286 & 533 & 1055 & 359 & 166 & 125 & 1055 & 303 & 140 & 102 \\
\hline $2 \mathrm{H} 138$ & 0 & 0 & 223 & 363 & & & 213 & 183 & & & 180 & 150 \\
\hline 1H059 & 7 & 17 & 270 & 314 & 617 & 505 & 177 & 211 & 617 & 425 & 149 & 173 \\
\hline 1H128 & 5 & 28 & 386 & 484 & 786 & 298 & 123 & 137 & 786 & 251 & 104 & 112 \\
\hline 1H133 & 8 & 33 & 383 & 564 & 528 & 253 & 124 & 118 & 528 & 213 & 105 & 96 \\
\hline 1H137 & 4 & 20 & 273 & 521 & 1003 & 425 & 175 & 127 & 1003 & 358 & 147 & 104 \\
\hline 1H139 & 3 & 21 & 349 & 504 & 1179 & 400 & 137 & 132 & 1179 & 338 & 115 & 108 \\
\hline VH056 & 10 & 38 & 389 & 548 & 389 & 219 & 122 & 121 & 389 & 184 & 103 & 99 \\
\hline VH090 & 6 & 27 & 293 & 505 & 680 & 314 & 163 & 131 & 680 & 265 & 137 & 107 \\
\hline VH097 & 9 & 35 & 379 & 665 & 451 & 239 & 126 & 100 & 451 & 202 & 106 & 82 \\
\hline VH100 & 10 & 40 & 434 & 622 & 418 & 208 & 110 & 107 & 418 & 176 & 93 & 87 \\
\hline 1H138 & 5 & 22 & 292 & 435 & 853 & 375 & 163 & 153 & 853 & 316 & 138 & 125 \\
\hline VH089 & 6 & 25 & 321 & 558 & 647 & 329 & 149 & 119 & 647 & 277 & 125 & 97 \\
\hline 1H080 & 4 & 17 & 113 & 113 & 1003 & 484 & 420 & 585 & 1003 & 408 & 354 & 479 \\
\hline VH058 & 3 & 11 & 159 & 203 & 1542 & 764 & 300 & 327 & 1542 & 644 & 253 & 267 \\
\hline
\end{tabular}


Table 4. Summary of irrigation scheduling for representative pivots: crop, plot size, diameter, inflow rate, irrigation time and days between irrigations for May to June and from July to August. Irrigation time and time between irrigation presented in this table corresponds to the most common values for the time considered, excluding the occasional extremes.

\begin{tabular}{|c|c|c|c|c|c|c|c|c|c|}
\hline Crop & Hydrant & $\begin{array}{c}\text { Total } \\
\text { Area } \\
\text { (ha) }\end{array}$ & $\begin{array}{l}\text { Inflow } \\
\text { rate } \\
\left(1 \mathrm{~s}^{-1}\right)\end{array}$ & $\begin{array}{c}\text { Seasonal } \\
\text { Irrigation } \\
\text { Time (h) }\end{array}$ & $\begin{array}{c}\text { Irrigation Time } \\
\text { May-June } \\
\left.\text { (h ha-1 event }^{-1}\right)\end{array}$ & $\begin{array}{c}\text { Irrigation Time } \\
\text { July-Aug } \\
\text { (h ha-1 event-1) }\end{array}$ & $\begin{array}{c}\text { Time } \\
\text { Between } \\
\text { Irrigations } \\
\text { May-June } \\
\text { (days) } \\
\end{array}$ & $\begin{array}{c}\text { Time } \\
\text { Between } \\
\text { Irrigations } \\
\text { July-Aug. } \\
\text { (days) } \\
\end{array}$ & $\begin{array}{l}\text { Irrigation } \\
\text { Depth } \\
\text { (mm) }\end{array}$ \\
\hline Corn & $2 \mathrm{H} 064$ & 55.9 & 75 & 1381 & 0.50 & 1.00 & 1.00 & 0.70 & 668 \\
\hline Alfalfa & 1H003 & 53.4 & 65 & 1493 & 3.37 & 2.97 & 4.50 & 4.30 & 675 \\
\hline Corn & 2H148 & 46.4 & 62 & 1343 & 1.50 & 1.50 & 0.50 & 0.90 & 646 \\
\hline Corn & 2H106 & 45.5 & 65 & 1295 & 0.85 & 0.86 & 1.40 & 0.50 & 667 \\
\hline Corn & 1H069 & 35.5 & 23 & 1781 & 1.00 & 8.00 & 2.50 & 9.00 & 533 \\
\hline Corn & 2H094 & 34.9 & 50 & 1472 & 1.15 & 1.13 & 1.37 & 0.52 & 760 \\
\hline Corn & 1H019 & 30.6 & 45 & 1514 & 1.71 & 2.90 & 0.86 & 1.20 & 777 \\
\hline Corn & 1H076 & 22.5 & 28 & 2067 & 3.01 & 4.63 & 2.89 & 1.12 & 772 \\
\hline Corn & 1H145 & 20.9 & 23 & 1833 & 2.39 & 1.77 & 1.51 & 0.62 & 701 \\
\hline Corn & 2H055 & 42.5 & 65 & 1566 & 0.70 & 2.92 & 1.61 & 1.55 & 704 \\
\hline Alfalfa & VH017 & 15.4 & 22 & 1781 & 2.40 & 15.63 & 1.65 & 8.62 & 860 \\
\hline Corn & 2H018 & 11.9 & 16 & 1412 & 1.44 & 6.78 & 0.66 & 1.18 & 665 \\
\hline Corn & 2H062 & 63.2 & 95 & 1652 & 0.42 & 0.70 & 1.00 & 0.75 & 897 \\
\hline Alfalfa & 1H121 & 39.6 & 50 & 1665 & 1.27 & 2.62 & 0.40 & 0.48 & 774 \\
\hline Alfalfa & $2 \mathrm{H} 113$ & 38.2 & 50 & 1281 & 1.79 & 2.40 & 1.92 & 1.96 & 628 \\
\hline
\end{tabular}


Table 5. Telecontrol data analysis for eight of the ten supervised plots. Seasonal irrigation time, Irrigation time per hectare and event for two representative periods of crop development (May-June and July-August) and interval between irrigation in days for the same two periods. . Irrigation time and time between irrigation presented in this table corresponds to the most common values for the time considered, excluding the occasional extremes.

\begin{tabular}{|c|c|c|c|c|c|c|}
\hline Hydrant & $\begin{array}{c}\text { Seasonal } \\
\text { Irrigation } \\
\text { Time (h) }\end{array}$ & $\begin{array}{c}\text { Irrigation } \\
\text { Time } \\
\text { May-June } \\
\text { (h ha-1 } \text { event }^{-1} \text { ) }\end{array}$ & $\begin{array}{c}\text { Irrigation } \\
\text { Time } \\
\text { July-Aug } \\
\text { (h ha-1 event-1) }\end{array}$ & $\begin{array}{c}\text { Time } \\
\text { Between } \\
\text { Irrigations } \\
\text { May-June } \\
\text { (days) } \\
\end{array}$ & $\begin{array}{c}\text { Time } \\
\text { Between } \\
\text { Irrigations } \\
\text { July-Aug. } \\
\text { (days) } \\
\end{array}$ & $\begin{array}{l}\text { Irrigation } \\
\text { Depth } \\
\text { (mm) }\end{array}$ \\
\hline $1 \mathrm{H} 014$ & 1311 & 2.7 & 5 & 0.5 & 0.9 & 769 \\
\hline $2 \mathrm{H} 043$ & 1924 & 1.8 & 2.2 & 1 & 0.33 & 1350 \\
\hline 1H002 & 1706 & 0.7 & 2.1 & 0.8 & 0.7 & 778 \\
\hline VH012 & 1615 & 1.2 & 1.25 & 0.85 & 0.5 & 694 \\
\hline 1H062B & 1957 & 1.6 & 3.7 & 1.6 & 1.6 & 867 \\
\hline 2H124 & 1028 & 0.6 & 0.75 & 1.1 & 0.66 & 626 \\
\hline 2H100 & 1532 & 1 & 1.25 & 0.66 & 0.25 & 699 \\
\hline 2H158 & 1380 & 2.34 & 2.77 & 0.5 & 0.5 & 780 \\
\hline
\end{tabular}


Table 6. Pressure transducer data analysis for the ten supervised plots. For each plot the crop, area, inflow rate, average and variation coefficient of irrigation pressure, average and variation coefficient of irrigation time per block and event and percentage of daily irrigation time were presented.

\begin{tabular}{|c|c|c|c|c|c|c|}
\hline Hydrant & Crop & $\begin{array}{c}\text { Area } \\
\text { (ha) }\end{array}$ & $\begin{array}{c}\text { Inflow } \\
\text { Rate } \\
\left(\mathbf{l ~ s}^{-1}\right)\end{array}$ & $\begin{array}{l}\text { Pressure }^{*} \\
\quad \text { (kPa) }\end{array}$ & $\begin{array}{l}\text { Irrigation Time } \\
\left.\text { (h block }^{-1} \text { event }^{-1}\right)\end{array}$ & $\begin{array}{c}\text { Daily } \\
\text { Irrigation } \\
\text { Time (\%) }\end{array}$ \\
\hline $1 \mathrm{H} 014$ & Long cycle corn & 7.5 & 10 & $438(3)$ & $0.95(16)$ & 50 \\
\hline $2 \mathrm{H} 043$ & Alfalfa & 9.3 & 12 & $389(1)$ & $1.91(36)$ & 51 \\
\hline 1H002 & Long cycle corn & 20.3 & 26 & $243(4)$ & $1.35(33)$ & 84 \\
\hline VH012 & Long cycle Corn & 13.5 & 16 & $356(2)$ & $1.11(31)$ & 16 \\
\hline 1H062B & Alfalfa & 18 & 22 & $328(4)$ & $2.86(17)$ & 34 \\
\hline 1H092 & Long cycle corn & 11.9 & 15 & $254(3)$ & $1.28(44)$ & 42 \\
\hline $2 \mathrm{H} 124$ & Short cycle corn & 26.6 & 32 & $318(3)$ & $1.47(34)$ & 20 \\
\hline 2H100 & Long cycle corn & 16 & 20 & $411(3)$ & $1.27(29)$ & 77 \\
\hline 2H158 & Short cycle corn & 9 & 16 & $346(4)$ & $1.48(33)$ & 8 \\
\hline 1H108 & Long cycle corn & 30.8 & 37 & $321(5)$ & $1.58(42)$ & 55 \\
\hline
\end{tabular}

*Average and Variation Coefficient (\%) 
Table 7. Telecontrol data analysis for four drip irrigated plots. Seasonal irrigation time, irrigation time per hectare and event for two representative periods of crop development (May-June and July-August) and time between irrigation in days for the same two periods. Irrigation time and time between irrigation presented in this table corresponds to the most common values for the time considered, excluding the occasional extremes.

\begin{tabular}{|c|c|c|c|c|c|c|c|c|}
\hline Hydrant & $\begin{array}{c}\text { Area } \\
\text { (ha) }\end{array}$ & $\begin{array}{c}\text { Inflow } \\
\text { rate } \\
\left(1 \mathbf{s}^{-1}\right)\end{array}$ & $\begin{array}{c}\text { Seasonal } \\
\text { Irrigation } \\
\text { Time (h) }\end{array}$ & $\begin{array}{c}\text { Irrigation } \\
\text { Time } \\
\text { May-June } \\
\text { (h ha }^{-1} \text { event }^{-1} \text { ) }\end{array}$ & $\begin{array}{c}\text { Irrigation } \\
\text { Time } \\
\text { July-Aug } \\
\text { (h ha-1 }^{-1} \text { event }^{-1} \text { ) }\end{array}$ & $\begin{array}{c}\text { Time } \\
\text { Between } \\
\text { Irrigations } \\
\text { May-June } \\
\text { (days) } \\
\end{array}$ & $\begin{array}{c}\text { Time } \\
\text { Between } \\
\text { Irrigations } \\
\text { July-Aug. } \\
\text { (days) }\end{array}$ & $\begin{array}{c}\text { Irrigation } \\
\text { Depth } \\
(\mathrm{mm})\end{array}$ \\
\hline $1 \mathrm{H} 141$ & 20.5 & 24 & 1314 & 0.50 & 0.60 & 0.70 & 0.90 & 513 \\
\hline 1H139 & 5.8 & 6 & 1324 & 1.93 & 1.44 & 0.50 & 0.75 & 500 \\
\hline VH100 & 2.1 & 4 & 1026 & 3.10 & 4.03 & 0.75 & 0.75 & 629 \\
\hline VH097 & 15.1 & 17.5 & 1568 & 0.52 & 0.85 & 0.60 & 0.43 & 665 \\
\hline
\end{tabular}




\section{List of Figures}

Fig. 1 Location of the Candasnos irrigation district. Distribution of pressurized irrigation systems (pivots, solid-sets and drip) and location of the supervised plots.

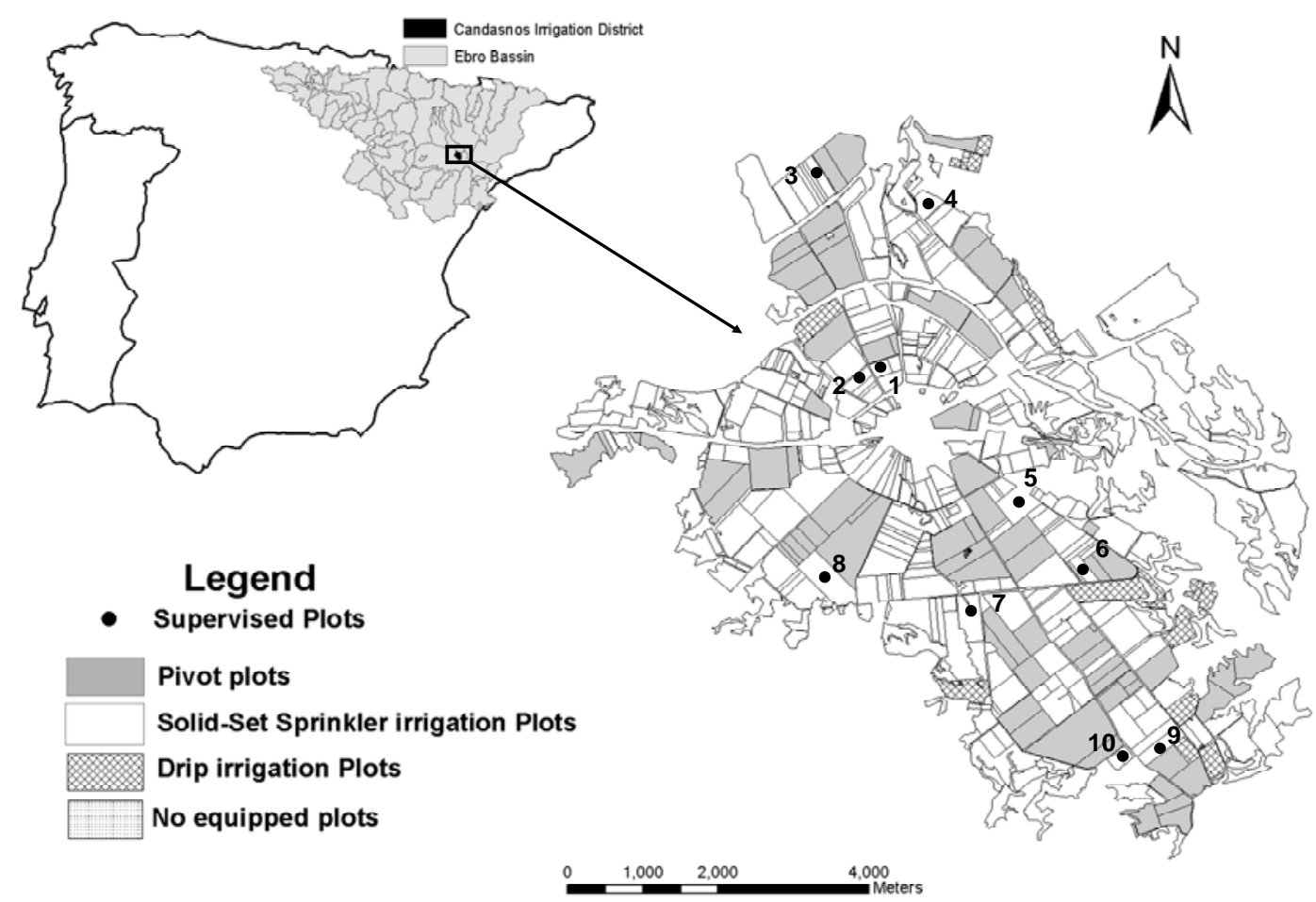



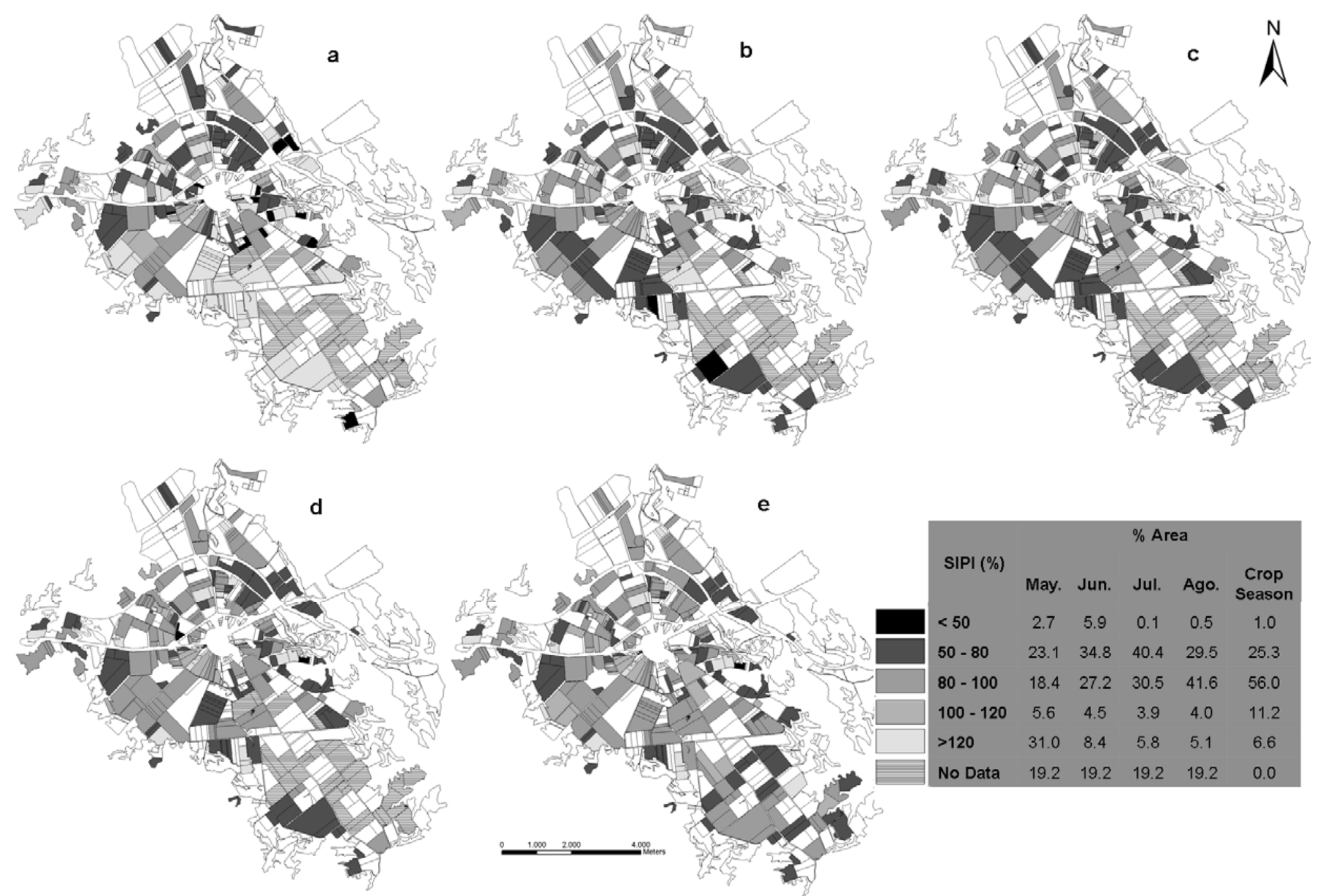

Fig. 2 Spatial distribution of the SIPI classes along the irrigation season for corn. Data are presented accumulated until (a) May, (b) Jun, (c) July (d) August and (e) the whole season. Table presents the percentage of area devoted to each ARIS class 

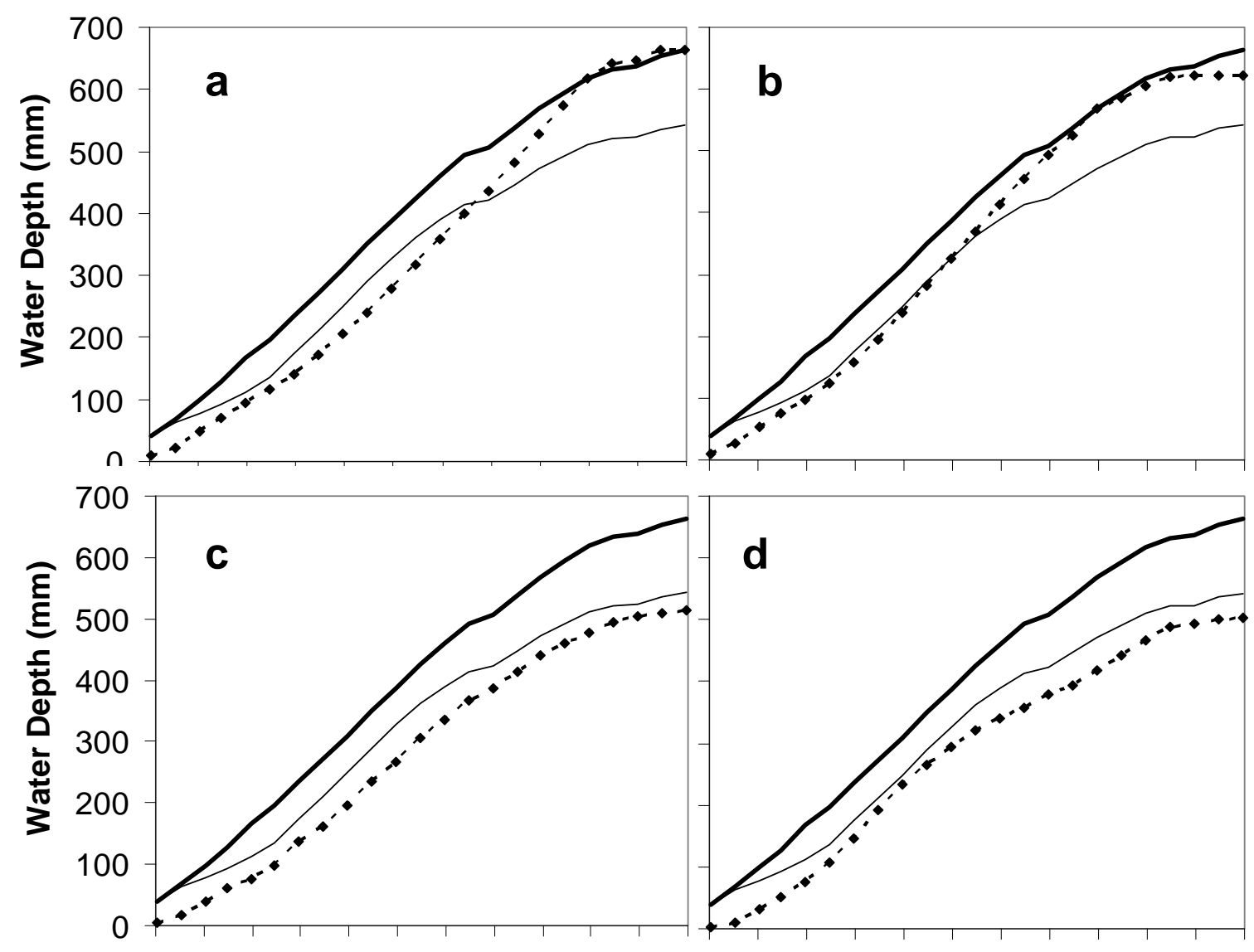

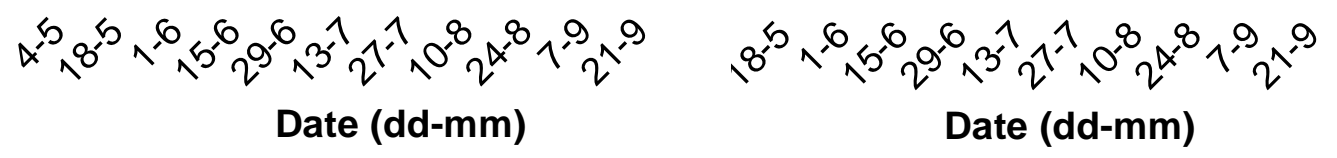

$$
\text { —NIR - NCDIR - - - Irrigation Depth }
$$

Fig. 3 Weekly evolution of cumulated irrigation water, standard crop irrigation requirements (NIR) and controlled deficit irrigation requirements (NCDIR) for four plots of medium cycle peach (VH097, CH100, 1H141 and 1H139). 

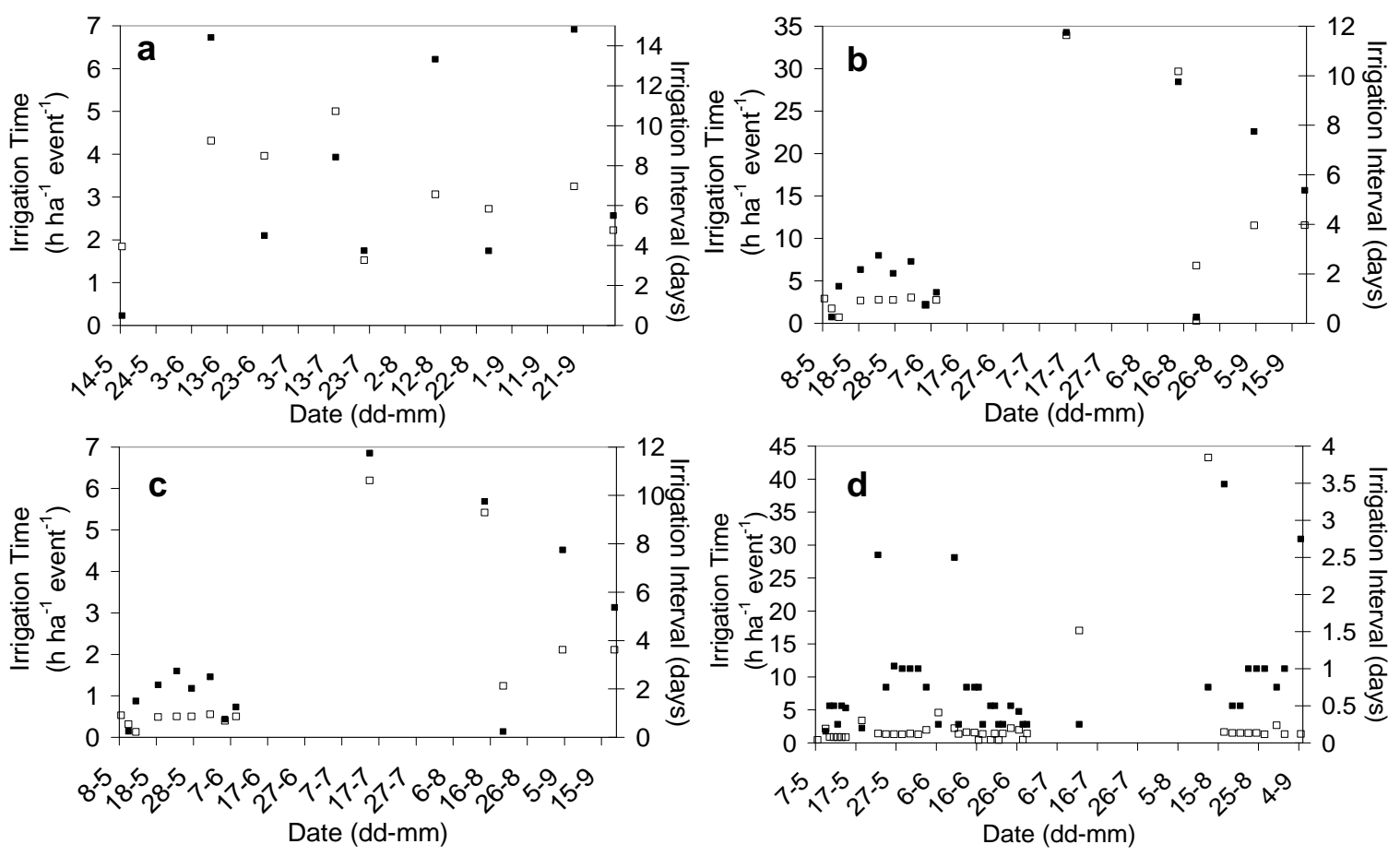

\section{- Irrigation Time $\cdot$ Irrigation interval}

Fig. 4 Evolution of the irrigation time (per hectare and event in hours) and the interval between irrigation (in days) during the irrigation season, for two alfalfa pivots (Figures $4 \mathrm{a}, 1 \mathrm{H} 003$, and 4b, VH017) and two corn pivots (4c, 1H069 and 4d, 2H018). 


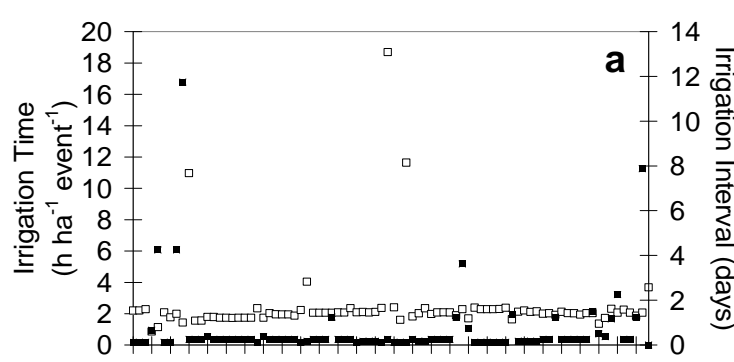

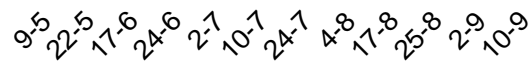

Date (dd-mm)

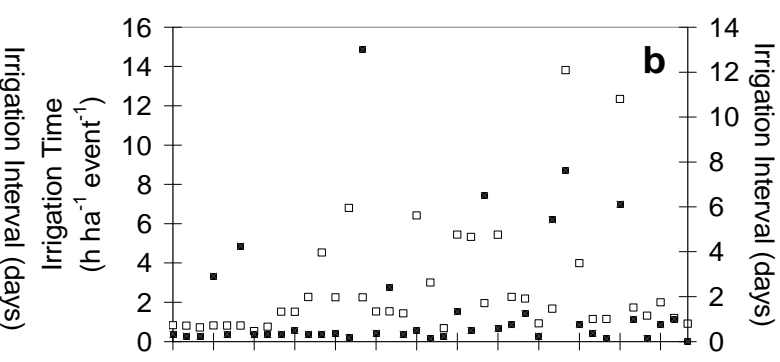

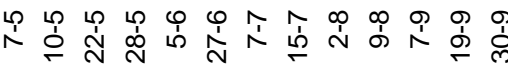
Date (dd-mm)

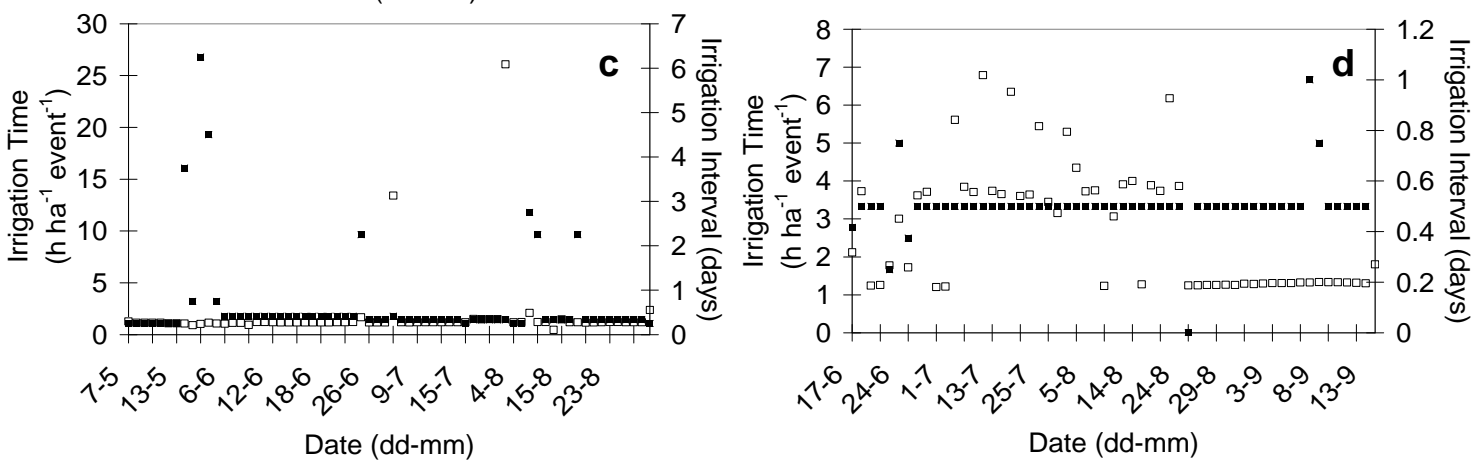

\section{口 Irrigation Time * Irrigation interval}

Fig. 5 Evolution of the irrigation time (per hectare and event in hours) and the interval between irrigation (in days) during the irrigation season, for two alfalfa solid set (Figures $5 \mathrm{a}$ and $5 \mathrm{~b}$, corresponding to hydrants $2 \mathrm{H} 043$ and $1 \mathrm{H} 062 \mathrm{~B}$, respectively) and two corn solid set (Figures $5 \mathrm{c}$ and 5d,corresponding to hydrants VH012 and 2H158, respectively). 

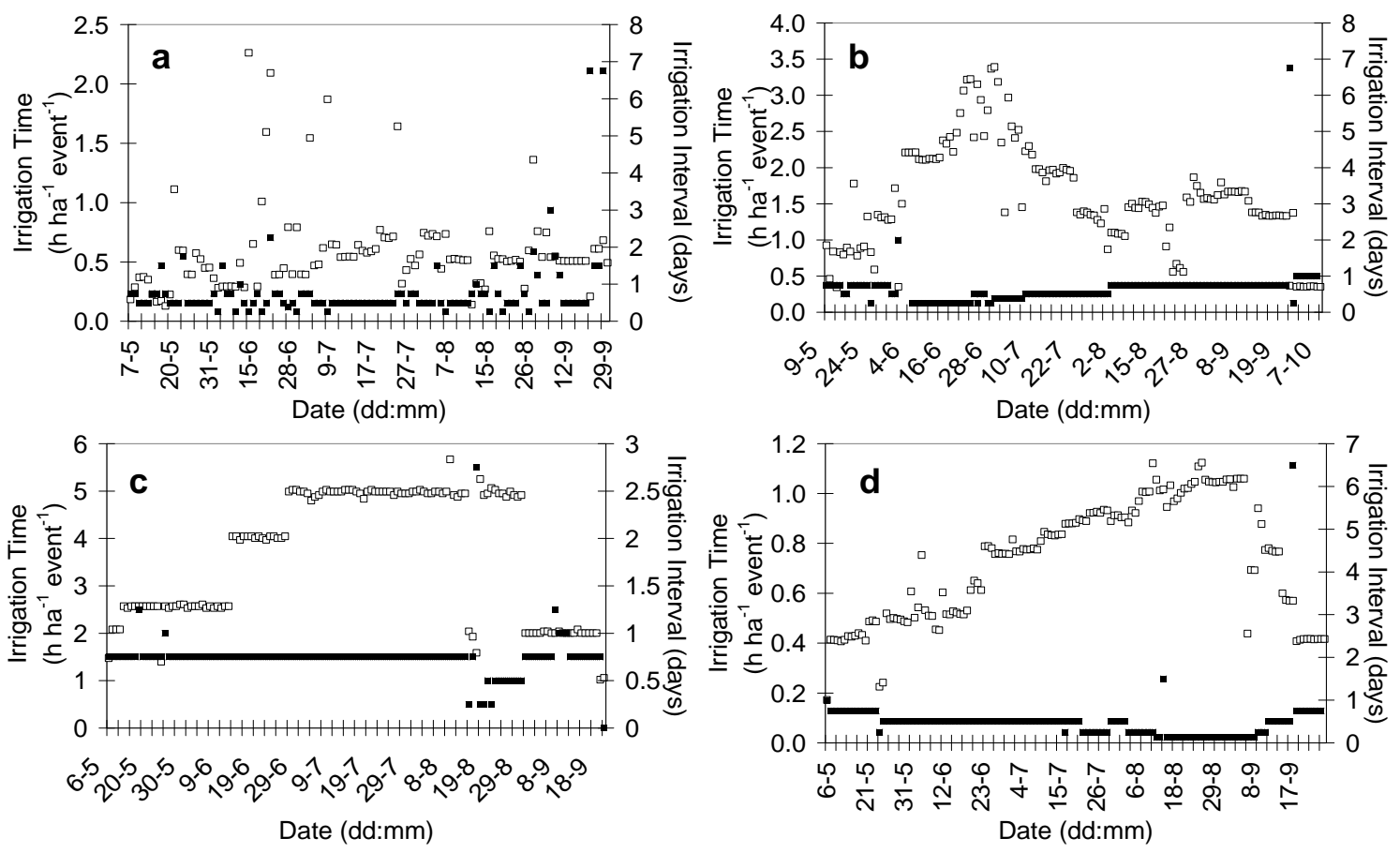

\section{- Irrigation Time - Irrigation interval}

Fig. 6 Evolution of the irrigation time (per hectare and event in hours) and the interval between irrigation (in days) during the irrigation season, for four drip irrigated plots cropped by peaches $(5 \mathrm{a}, 1 \mathrm{H} 141,5 \mathrm{~b}, 1 \mathrm{H} 139,5 \mathrm{c}, \mathrm{VH} 100$ and $5 \mathrm{~d}$ corresponds to hydrant VH097). 